\title{
CLIL - a Dialogue between the Language and Subject Teachers
}

\author{
Ivana Cimermanová
}

Institute of English and American Studies, Faculty of Arts, University of Prešov

\begin{abstract}
Content and language integrated learning is one out of the bilingual methods that has been frequently discussed by language teachers, researchers and scholars for the last decade in Slovak educational environment. Mostly they are positive about the benefits CLIL offers for learners and they study both results in language and subject achievement; moreover, they investigate its impact on teachers' competencies and feasible integration of language and content. The article outlines general definition of the CLIL term; illustrates its benefits and drawbacks; discusses the competencies of a CLIL teacher; deals with an issue of materials and takes closer look at integration of English language and Mathematics teaching.
\end{abstract}

Keywords: CLIL, foreign language, CLIL teacher, mathematics, competencies.

\section{Insights into CLIL}

The acronym CLIL is one of the buzz terms not only in foreign language teaching but teaching generally. The term was coined by David Marsh and it stands for Content Language Integrated Learning (in Slovak language - jazykovo-obsahové integrované učenie sa). Its name directly indicates the aim of the methodology, namely to teach subjects as science, geography, arts through a foreign language. Marsh (2002, p. 65) defines CLIL as "dual-focused methodological approach that embraces both language and non-language content, focusing mainly on 'meaning'." In those situations, a foreign language functions as a means of communication rather than the aim of teaching and language learning becomes meaningful what leads toward better long-term retention (see Brown, 2015). Despite an enormous expansion of CLIL in the European area in recent years, it has already been used for centuries "to provide linguistically-enhanced education which results in certain youngsters leaving school with the plurilingual ability to use two or more languages." Some forms of CLIL have been used in order to improve speech training of some gifted students (Marsh, n.d., p. 9). The great advantage according to Marsh (ibid, p. 6) is that "CLIL offers opportunities to allow youngsters to use another language naturally, in such a way that they soon forget about the language and only focus on the learning topic."

One of the basic characteristics of CLIL is duality of aims: language and content. The content aims focus on the development of the cognitive functions of the learners, the aim of 
the language teaching in CLIL is to develop predominantly communicative competence in the target language. The research results indicate positive effects of CLIL (Pica, 2002). However, CLIL does not only mean teaching in a foreign language; it means teaching through this language and that is much more cognitively demanding and complex process. CLIL embraces cognitive development, raising cultural awareness and increases learners' motivation (Doiz, Lasagabaster and Sierra, 2014; Lasagabaster and Belouqui, 2015) because it offers some kind of authenticity and challenge.

Understanding and application of CLIL differs. Ouazizi (2016, p. 128) states that one of the benefits is that CLIL "offers 'repetition' of the syllabus learned in the mother tongue gives additional time and opportunity to the students to revise and fix what they have been learning in their mother tongue." This is however, not fully compatible with the position of those CLIL teachers who believe that subject teaching and language teaching should be complementary, integrative rather than repetitive. Duality of aims means follow two aims at the same time, rather than two individual aims during two separate units - first to teach content and then to teach the same content in foreign language. In case of repetition we give extra time to master the content and language. Still, the integration has to consider the learners and both their cognitive and language abilities. Naturally, language can be simplified, however "If the simplification leads to the trivialization of the content and does not favour the proper cognitive growth of the students, then the CLIL approach is not being implemented" (Costa, D'Angelo, 2011, p. 9). On the other hand, the learning of content should be achieved at comparable level to that taught in the native language.

We have already partly mentioned the positive aspects and benefits of CLIL. application. Vašíček (2008) defines the following aims of CLIL application:

- to provide the opportunities to communicate in target language;

- to expand vocabulary and explore the language of subject (e.g. in mathematics the terms such as add, subtract, multiply, divide, etc);

- to use the target language in the class activities;

- to change attitudes towards foreign language teaching;

- to enrich the traditional school curriculum.

Those general aims can be specified based on the perspective of the positive impacts on learners. Pokrivčáková (2010, p. 8) identifies the following:

- learners work on the contextualised tasks;

- the language is used in the meaningful context, natural conditions (they really communicate, do not use language in artificial situations);

- learner's concentration is primarily focused on the content of communication rather than on language itself (what significantly lowers the anxiety connected with making mistakes); and it also corresponds with the conditions in real communication;

- necessity to use prior knowledge and experience (including inter-subject experience);

- development of other foreign language communication competencies (intercultural, aesthetic, etc.). 
Blondin et. al (cf. Navés, Muñoz and Pavesi, 2002, p. 36) claim that "The effects of age on instructed foreign language acquisition may, however, not be the same as on naturalistic language acquisition." They stress that "the amount and quality of the input is very different, and this has a direct consequence on the period of time the younger learners will need before they surpass the older students" (ibid). The early beginning, or start of foreign language learning does not automatically mean advantage. Marsh (2002, p. 74-75) similarly assumes that age is a factor that never works on its own and stresses the importance of educational context; he notes that naturalistic context compared to the instructional one brings "quicker and more immediate advantages." At the same time, he warns that "High exposure CLIL/EMILE introduced at secondary level in academic subjects where the target language competence is either heterogeneous or not sufficiently advanced can reportedly have a negative impact on learning outcomes."

The extent to which L1 (mother tongue) and L2 (target language) are used is not set. The authors suggest different ratio. Papaja (2014, p. 47) states that "it is useful to consider L1/L2 ratio of $75 \% / 25 \%$ as a minimum starting point for CLIL." Even though the use of L2 is relatively low in this case CLIL is perceived as "means of enriching rather than constraining the learning context" (ibid). Pokrivčáková (2010a, p. 83) categorises 2 main types of CLIL according to the amount of foreign language use - additive and immerse; additive type is subdivided into two subtypes according to the length of exposition (low exposition (5-15\%) and medium exposition (15-50\%)). Immerse type is defined as a type with high exposition type (50-100\%). "Research suggests that the intensity and timing of exposure (qualitative) may be more important than high exposure (quantitative), particularly with certain types of learners. Small-scale long-term exposure is therefore being viewed positively. Early introduction (4-12 years) is now increasingly under discussion as advantageous. There is no available evidence which would support the view that low (5-15\% of teaching time) to medium exposure (15-50\% of teaching time) would threaten the first language" (Marsh, 2002, pp. 9-10).

Gary Anderson (2012) categorises CLIL based on the way of its application. In case that CLIL is applied by the subject teachers he names it real CLIL; on the other hand, in case of language teacher applying CLIL he uses the term "lite" CLIL. He highlights the selected aspects of teaching, starting with language (level), techniques (that might be common for language teacher (different types of activities, forms, methods, types of interaction, etc.), that might be not "common" for subject teacher), evaluation (what should be assessed content or language progress), he also discusses materials (that might be a problem, as the selected text, resp. its content does not necessarily must correspond with curriculum). In academic literature we find the terms soft CLIL and hard CLIL - in soft CLIL we deal mainly with the language aims and integration of subject teaching into language learning. On contrary, if CLIL is applied in subject teaching we deal with hard CLIL. 


\section{CLIL in Slovakia}

CLIL is gradually coming into Slovak schools. In 2012 Pokrivčáková (pp. 68-69) stated that CLIL implementation in Slovakia could be compared to other countries and it copied the progress in other countries. She supported the statement by comparison with the research results conducted by Lasagabaster and Sierra (2009) and Dalton-Puffer (2011, pp. 183-184):

- typically, less than $50 \%$ of the communication in CLIL lessons is run in target language;

- dominant CLIL language is English;

- Integrated CLIL language is not regularly used in the wider society;

- CLIL lessons are usually timetabled as content lessons (e.g. mathematics, science, arts, $\mathrm{PE}$, etc.) and not as a part of language lessons;

- target language is taught as a subject in its own right;

- for majority of learners CLIL lessons and EFL lessons are the only possibility for communication and interaction in target language;

- vast majority of CLIL teachers in Slovakia are non-native speakers of the target language.

Dalton-Puffer (2011) research showed that majority of CLIL teachers are subject teachers rather than language teachers. Pokrivčáková (2012), Sepešiová (2014) react and they both state that there should be further research focused on CLIL teacher and the way how CLIL is realised in Slovak conditions, especially who is the CLIL teacher and which subjects is CLIL applied in. So far, there has not been research conducted to find out who, subject or language teachers, teaches CLIL lessons in Slovakia. Similarly, there is no agreed recommendation on what age is the most appropriate for CLIL application. There are a number of published studies (e.g., Sepešiová, 2014; Trníková, 2015; Pokrivčáková, 2010) that studied the possibilities and effects of CLIL application as early as in primary level. National institute for education in Slovak republic ran a project (September 2008 - December 2012) with the aim to pilot CLIL in Slovak schools. There is list of 17 elementary schools publishes on their website that currently apply CLIL (10 schools English language, 2 German Language, 4 German and English languages and 1 school Roma and English language).

Vanková (2012, p. 33) mentions that in 2008 there were only 6\% of the studied elementary and secondary schools in Czech Republic applying CLIL whereas the number increased to 24 in 2011. CLIL has become "fashionable" in Slovakia as well. Ministries, advisory boards talk about CLIL (frequently in connection with plurilinguism), but the idea of the possibility to introduce CLIL to schools has to undergo deep analysis to find out whether the conditions for effective applications can be provided. Jeremy Harmer (2011) in his blog raises several questions that do not dispute CLIL methodology but rather forces and challenges the reader to think before a quick decision. He concerns especially the fact that we (mostly language teachers) mostly speak about the language teaching, benefits of target language development and asks whether subject teachers are also so positive about its benefits in subject learning. 


\section{CLIL teacher - a language or a subject one?}

CLIL is an approach that needs a teacher who is competent in the subject, field of teaching and at the same time proficient language user depending on the type of integration. Generally, the CLIL lesson (unit) can be taught by a language teacher who understands the content subject or the subject teacher who speaks target language. Concerning teacher language abilities, it is not necessary that his competencies are native-like, even though they have to be fluent and accurate to certain extent. The recommended level of Language knowledge and performance is B2 - C1 (according to CEFR; in Netherlands teachers have to pass the test at $\mathrm{C} 1$ level, but there are also countries where the B1 level is accepted). In Slovak context most universities offer teacher-training programmes as double major programmes. However, this does not automatically mean that a group of our graduates are ready for CLIL application. Similarly, primary school teachers in lower grades (K1 - K4) have perfect knowledge of the content taught in all subjects and thus they do not have problem to integrate content and knowledge. Generally, we do recommend that subject and language teachers should closely cooperate what can also have a positive effect on their professional development. if teachers want to apply CLIL approach properly, they should be aware of CLIL functioning and basic principles (Sepešiová, 2014). Discussing competencies of CLIL teachers, it includes mostly specific lesson planning and organizing. It is also important to know how to deal with materials suitable for learners not only according to the topic of the non-language subject but also according to the age and level of proficiency of learners (Sepešiová, 2014, p. 120; Pavesi, et al., 2001, p. 101, Bertaux, et al., 2010; Sepešiová, Straková, 2013). Moreover, they should support critical and analytical thinking; cooperate with other teachers; prepare such activities and supplementary materials along with different forms of teaching and motivation to develop learner's skills, their competencies and knowledge. As shown in the research of Dafouz et al. (2007), tertiary institutions should prepare and foster teachers not only with a solid knowledge of what CLIL really means but also with the effective tools needed for applying the above mentioned a dual focused approach.

\section{Integration and CLIL materials}

CLIL methodology allows to expose learners to foreign language in a quasi-natural environment, authentic situation and even though the time of exposure is shorter compared to foreign language classes it is expected that the impacts of such organisation of learning will be more intensive. The main focus is on the content; curricular content leads language teaching. This is also considered in the evaluation that focuses on the content and not language achievement what means the language barriers is surmounted and the risk-taking is higher. Concerning language, we do not expect language perfection but rather the ability to understand the written text and to pass the message.

It has been already mentioned that in CLIL we deal with integration of language teaching and subject content; what means for the learner that language becomes means of communication and not the target of learning. It is necessary to define the topic that integrates 
a target language and the subject content. Than it is important to define two aims, namely language and content aims. Preparation of the appropriate material is important, necessary step in planning as in CLIL there are two aims that have to be fulfilled. It has been mentioned that the textbooks contain the CLIL material, however, it has to be admitted that the focus is primarily on the development of the language competence. Mehisto (2012) defines 10 basic criteria that should be carefully considered while quality materials for CLIL:

1. make the learning intentions (language, content, learning skills) \& process visible to students;

2. systematically foster academic language proficiency;

3. foster learning skills development and learner autonomy;

4. include self, peer and other types of formative assessment;

5. help create a safe learning environment;

6. fostering cooperative learning;

7. seek ways of incorporating authentic language and authentic language use;

8. foster critical thinking;

9. foster cognitive fluency through scaffolding of a) content, b) language, c) learning skills development helping student to reach well beyond what they could do on their own;

10. help to make learning meaningful.

Generally, we may state that currently the language textbooks offer plenty of materials that can be considered CLIL, as they offer the content connected with other subjects. The typical example of such materials are the texts about English speaking countries, their history, geography, culture, etc. This material, however does not systematically follows the aims of the content language. They are a part of language textbook; the content is well written but not necessarily considers language learners and their curriculum what is natural - the textbook can not correspond to all national curricula. Still, they are very good material for teachers preparing their CLIL units. Boynton (cf. Mehisto, Marsh a Frigols; 2008, pp. 105-109) summarises essential elements teachers should consider in CLIL lessons to support language learning in content lesson:

1. create a psychologically and physically safe environment,

2. consistently use one language,

3. In the beginning, it is acceptable for students to use the first language,

4. speak slowly and articulate clearly,

5. use an appropriate level of language,

6. use facial expressions, gestures and pictures to reinforce meaning,

7. repetition is required,

8. make it meaningful,

9. provide a variety of language models,

10. create wealth of opportunities to use the language,

11. communication is of primary importance, 
12. create a wide variety of opportunities to develop all four language skills - listening, speaking, reading and writing,

13. work systematically to build equal status for languages used in the school,

14. set high, but realistic expectations,

15. find ways of recognising student effort and success.

CLIL is often associated with $4 \mathrm{C}$ - content, communication, cognition, culture (in Slovak language we can speak about OK3; obsah, komunikácia, kognícia, kultúra). Coyle (1999) talks about the necessity to plan content (academic subject), language means, what learning processed will be applied and cultural aspects that will be presented (usually comparison of the target and own culture). Skeet (2011) enriches the theory and suggests another 4C (collaboration, choices, creativity, connections). Collaboration has to be perceived at two levels. Cooperation between the teachers - subject teacher and language teacher, but also cooperation of learners in a lesson (different projects, problem-solving, task-based learning, etc.). The second $\mathrm{C}$ stands for choices - choice that should be given to students. This stresses the personality of students, different learning styles, different language proficiency and the possibility to choose their own way of learning. Skeet (ibid) highlights creativity as a significant aspect of effective teaching, but again, not only concerning learner and activities that should be creative, but also the teacher who should be creative as soon as in a planning phase, $\mathrm{s} /$ he should be ready to experiment as well as should be ready for non-traditional, non-conventional situations in the class. In CLIL lessons various types of connections can be observed. Not only the connection between the language and content, but looking for connections between the individual steps, it is important to make sure that students do not perceive language as a target but rather as a means. Another connection that has to be mentioned is the connection with the learners' prior knowledge, but what more, connection to real life situations and the possibility to use/connect the learnt material in real-life situations.

Evaluation is the issue frequently discussed when dealing with CLIL. Here, again, we find more information on language rather than on content. Most frequently we find the opinion that content is dominant and in this sense, we should evaluate the learners and deal with errors. Ernst (1995) defines 4 types of errors occurring in CLIL lessons:

1. Errors of a phonological, morphological, syntactic, semantic or pragmatic nature that impede or impair understanding should be corrected and assessed as they would not allow effective communication.

2. So-called pragmatic errors, i.e. errors of register, which are inappropriate in respect to a specific culture or situation, should be corrected. As intercultural competence is a specific learning goal of CLIL, empathy for different people and cultures should be developed.

3. Errors of form that occur in phonology, morphology, syntax, or lexis are deviations from grammar rules but do not impede understanding. Therefore, they should be judged more leniently than in language lessons. 
4. Errors in content-specific terminology, he argues, are part of content and should be corrected and assessed, in particular with regard to terms that have been previously dealt with in class.

Out of four types of errors he defined, three deal with language teaching/learning and just one deals with the content/subject education. Evaluation of language errors focusses on fluency (what corresponds with the CLIL aims).

\section{Mathematics and cross-curricular teaching}

Marsh (n.d., p. 8) stresses that CLIL does not only support language competence development. What more, and this is important for content teaching "Because of the different 'thinking horizons' which result from working in another language CLIL can also have an impact on conceptualization, literally how we think. Being able to think about something in different languages can enrich our understanding of concepts, and help broaden our conceptual mapping resources. This allows better association of different concepts and helps the learner go towards a more sophisticated level of learning in general."

CLIL is often applied in science subjects. In science subjects we often rely in visual stimuli, on non-verbal presentation what help learners to understand the content. Different approaches are presented and suggested for CLIL lessons. Publishers try to help the teachers by publishing different materials, textbooks and websites for CLIL. Numerous courses (even massive open online courses (MOOCs)) are available. Guidance offered in the teacher's book in Oxford CLIL Natural Sciences Pack is based on the knowledge of the experienced CLIL teachers and the authors' recommendations include (2013):

- the subject comes first,

- long, dense texts and complex sentences should be avoided,

- presentation of material should be supported by visual stimuli, pictures, tables, labels,

- learning must be guided and structured,

- comprehension tasks will be used more frequently than in a native language context,

- learning is active wherever possible,

- the emphasis is in the process of learning,

- the four skills are crucial for presenting and lecturing new information.

Cambridge ESOL published a set of booklets for teaching subjects through English (e.g. Teaching Geography through English - a CLIL approach; Teaching Math through English a CLIL approach) where they discuss two types of language in CLIL lessons; namely content-obligatory and content-compatible language. Content compatible language is the non-subject specific language. It is the language that might have been learnt before and is generally used to communicate in everyday life (e.g. letters of alphabet, numbers, the vocabulary like line, point, small, large, connect, rain, water, the phrases like this means, the start of river. The content-obligatory language is associated with the specific content of the particular subject. This means it is a language learners need to communicate the subject knowledge (e.g. delta, meander; axis, linear graph, etc.). Tejkalová (2010) stresses 
that in mathematics teaching we deal not only new language and new content, "but also the symbolic and iconic "language of mathematics", which offers both positives (symbolic/iconic language offering a natural bridge between L1 and L2) and negatives (requiring the competence to linguistically interpret the language of mathematics in its different modifications, or narrowing the meaning of words used in mathematical context etc.)."

"Mathematics educators and researchers suggest that to effectively teach mathematics means to humanize mathematics for its learners" (Toor, Mgombelo, 2015, p. 3276). Tennant (2002) defined that humanistic mathematics "guides students through mathematical ideas by the use of imagery, history, as well as other interdisciplinary connections. It may also involve innovative classroom strategies involving collaborative groups, the Internet, and teaching techniques that pique student interest and clarify mathematical ideas. At its very best, humanistic mathematics creates a learning environment that is productive, meaningful, and enjoyable for students." Foote et al. (2011, p. 71) conclude that to be a successful mathematics teacher one "must develop multiple expertise in knowledge of mathematical content, pedagogy for teaching mathematics, and knowledge of students." Concerning CLIL teacher, we have to add that one must have command of foreign language.

There is plethora material for teaching mathematics published in English language. However, not all of them are appropriate for CLIL lessons. It is also important to consider when the material is to be used; in the subject lesson or in the foreign language lesson and naturally, what are the aims. The special textbooks for CLIL lessons are published, however those books cannot fully follow the national and school curricula and school curricula and/or syllabi.

Tennant (2012) in his article suggests different materials for interdisciplinary teaching of mathematics. He presents the paintings, pictures of buildings and indicates how to interconnect them with the mathematics content and to show learners the relevance and possible use of presented stuff in real life. Similarly, Toor and Mgombelo (2015) present non-traditional way of teaching mathematics. They discuss the possibility to use storytelling in math teaching. Modi (2012) explain that stories in the mathematics classroom can be used to create "an environment of imagination, emotion, and thinking." She stresses that using stories in mathematics teaching makes lesson more enjoyable and memorable; students re more involved and engaged and stories "make them think and explore, and to help them understand concepts and ideas" (p. 31). Modi (ibid), however, stresses that in case of math teaching it is not possible to think about storytelling in terms of its own sense. She claims that stories are told occasionally in math, still in her research she does not deal with fictional stories about the topic, but rather with how the topic can be shaped to enhance its attraction to students. She highlights that "the great power of stories is in their dual mission: they communicate information in a memorable form and they shape the hearer's feelings about the information being communicated." Toor and Mgombelo (2015) report the positive effect of storytelling in teaching mathematics not only for students, but also for teachers. 
Ward-Penny (2001) in his book Cross-Curricular Teaching And Learning In The Secondary School: Mathematics discusses the authenticity and context for math application that cross-curricular teaching bring (necessity to apply maths in e. g. arts, geography, cooking); increase of motivation in cross-curricular teaching - "Teaching with an awareness of the wider curriculum allows the mathematics teacher to demonstrate the importance and relevance of mathematics" (p. 6) and it also allows integration of skills. Ward-Penny generalises that "cross-curricular approaches to teaching mathematics offer a range of ways of enhancing pupils' mathematical learning so as to address these needs and concerns" (p. 2). Previous studies of Nunes et al. (1993) have demonstrated and revealed that people's mathematical performance often depends on whether they are in school or in a real-life situation what support the idea of cross-curricular teaching and possibly CLIL as well.

\section{Mathematics and foreign language teaching integration}

When talking about language teaching integration of other subjects is in some way natural to certain extent. The topics discussed usually relate to other subjects and use /apply learner prior knowledge or bring new information. This is, however done based on foreign language syllabus. Communication about the profile of the learner, learner needs across different subjects, however, leads to cross-curricular topics than can be used in planning teaching both, subjects and language. This makes learning more meaningful as opposed to rote learning, it enables to create more associations and thus lead towards better understanding, reinforcing and deepening the knowledge. Concerning storytelling mentioned above, it is a common activity in language classes. In language classes it is used to present not only some facts, engage learners but it is frequently used to present new language in context (not only vocabulary, phrases but also structures, grammatical issues, etc.), culture, etc.

Strategies applied in mathematics and language task solving can be similar or different to certain extent. The book How the Brain Learns Mathematics discusses different strategies with respect to the age of learners and David Sousa, the author of the book, compare the mathematical texts and texts students are taught to write in their language classes. "For example, students learn that an author's main idea usually appears in the passage's opening sentences. In mathematics problems, however, the main idea often appears in the last sentence. Here's a typical example:

Billy is sorting out blue, green, and yellow marbles into single color groups. He has 58 marbles altogether. There are twice as many blue marbles as green marbles, and three more yellow marbles than blue marbles. How many marbles of each color does Billy have?" (p. 155).

We have already mentioned that integration is beneficial not only concerning content but also e.g., applying particular processes, learning strategies, etc. Halladay and Neumann (2012) present similarities between strategies used in reading comprehension and solving mathematical problems, namely they discuss making predictions, monitoring understanding, determinations of importance and making connections. Barton and Heidema (2002) in their book summarise 35 reading strategies and define how these could be used 
in mathematics instruction. The above-mentioned similarities can be used to develop learning strategies and these are transferable to any subject.

Language is a system. This system is based on rules and understanding the rules increases the speaker's accuracy. Many grammatical issues can be easily explained applying the mathematical principles and symbols. Learners with prevailing logical-mathematical intelligence are usually very good in learning grammar, they are very good in deducing and applying the grammar rules. Developing logical, critical thinking, reasoning, rules findings develop the skills that are necessary for life and their application on language learning enhances the education process.

Concerning language learning and mathematics there are common areas that can be found and create the space for CLIL applications. Numbers, shapes in groups of young learners; word problems, quizzes, logic puzzles, operators with older students; special mathematical terminology with secondary school student. The following pictures (figure 1 and figure 2) are examples form the Math textbooks (topic Shapes).

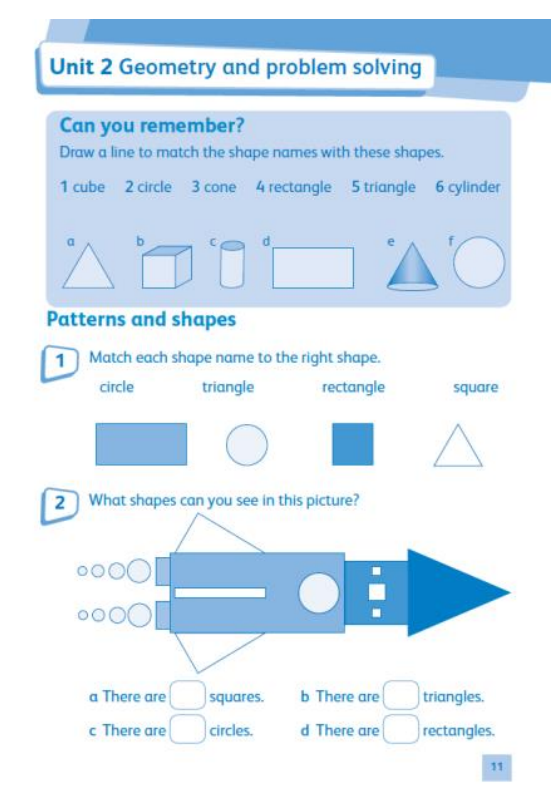

Figure 1: Source: Wrangles P. (2017) Hodder Cambridge Primary Mats: Workbook. London : Hodder Education.

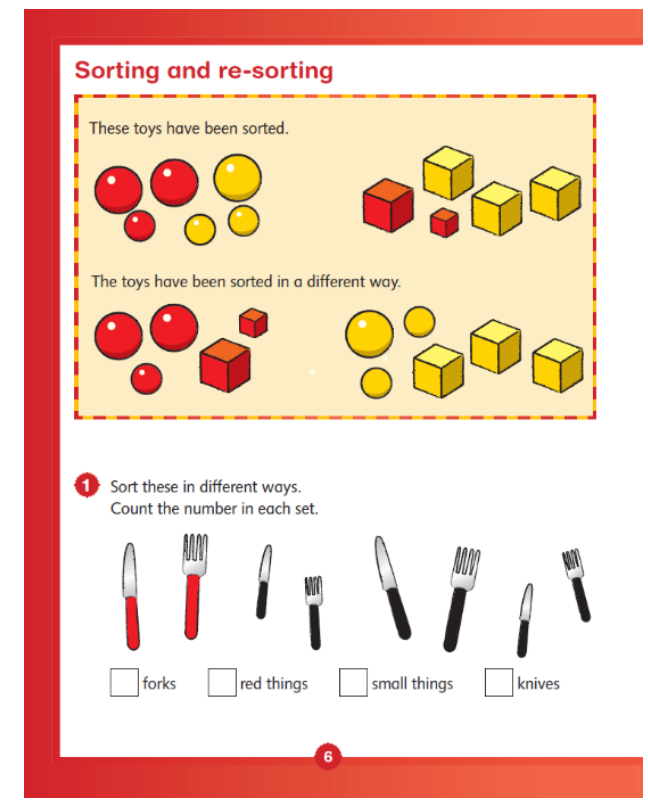

Figure 2: Source: Broadbent, P. (2009) Macmillan Mathematics Level 1A Pupil's Book ebook Pack. Oxford : Macmillan Education.

Brišová (2013) in her diploma work focused on English language and Mathematics integration within secondary education. Hence, she designed, tested and verified specific CLIL materials related to the Combinatory, Probability and Statistics at secondary grammar school. Her findings also showed that the learners welcomed innovation and the motivation towards language learning increased.

\section{Conclusion}

This paper has given an account of and the reasons for the widespread use of CLIL and scientifically oriented subject. From a language point of view, the CLIL approach contains 
nothing new to FL teachers. CLIL aims to guide language processing and support language production in the same way as ELT by teaching strategies for reading and listening and structures and lexis for spoken or written language.

Not only positives are connected with subjects integration. Naturally there are also threats and weaknesses that have to be discussed. No sufficient teacher with training in CLIL methodology is one of the cardinal problems but it is not insoluble. The institutions providing the courses for in-service teachers frequently offer the issue of CLIL into their programmes.

Many teachers report the possible terminological problems (lower fluency) in mother tongue, that are often the subject of the discussions about the bilingual education. In CLIL, however, we deal with immersion when both, mother tongue and target language are used what created space for building terminology in both languages.

Lesson preparation is not only time demanding but it is also associated with the material preparation. On the other hand, the number of ready-made-materials is constantly and rapidly growing (especially for soft CLIL; various lesson plans, handouts, but also software for interactive whiteboards, etc.), available free of charge at various websites and portals.

CLIL can be beneficial, but it should be applied constructively, the philosophy should be followed, what means the ad hoc solutions can be accepted but to create positive, supportive and challenging atmosphere it would be best if it is introduced as school philosophy and the aims and plans are discussed carefully at school level, rather than between two teachers.

\section{Bibliography}

1. Anderson, G. 2012. CLIL Won't Kill I \& II. In Cambridge English Teacher. Retrieved January 10, 2013, from 〈http://www.cambridgeenglishteacher.org/eventdetail/1123〉.

2. Anonymous (n.d.) Teaching Maths Through English. A CLIL Approach. Cambridge : Cambridge ESOL, University of Cambridge.

3. Barton, M. L., \& Heidema, C. 2002. Teaching reading in mathematics: a supplement to Teaching reading in the content areas. Aurora, Co.: Mid-Continent Research for Education and Learning.

4. Bertaux, P., Coonan, C., Esús Frigols, M., \& Mehisto, P. (n.d.). The CLIL Teacher's Competences Grid - Clilblog. Retrieved January 30, 2018, from /https://clilblog.files.wordpress. com/2010/04/clil_competences_grid_31-12-091.pdf).

5. Broadbent, P. 2009. Macmillan Mathematics Level 1A Pupil's Book Pack. Oxford : Macmillan.

6. Brown, H. D. 2015. Teaching by Principles: An Interactive Approach to Language Pedagogy. White Plains, NY : Pearson Education.

7. Dafouz-Milne, E., Núñez, B., Guinda, C. S., \& Foran, D. 2007. Integrating CLIL at the tertiary level: teachers' and students' reactions. In Diverse Contexts - Converging Goals. CLIL in Europe (pp. 91-101). Peter Lang.

8. Doiz, A., Lasagabaster, D., \& Sierra, J. M. 2014. CLIL and motivation: the effect of individual and contextual variables. The Language Learning Journal. 42(2), 209-224. doi:10.1080/09571736.2014.889508. 
9. Foote, M. Q., Smith, B. S., \& Gillert, L. M. 2011. Evolution of (Urban) Mathematics Teachers' Identity. Journal of Urban Mathematics Education. 4(2), 67-95.

10. Halladay, J. L., \& Neumann, M. D. 2012. Connecting Reading and Mathematical Strategies. The Reading Teacher. 65(7), 471-476. doi:10.1002/trtr.01070.

11. Harmer, J. 2011. To teach English is human, to teach CLIL is divine? Retrieved January 21, 2018, from 〈https://jeremyharmer.wordpress.com/2011/01/25/to-teach-english-is-human-to-teach-clil-is-divine/ $>$.

12. Lasagabaster, D., Linguarum, P. 2015. The impact of type of approach (CLIL versus EFL) and methodology (book-based versus project work) on motivation. Porta Linguarum 23. 41-57.

13. Marsh, D. 2002. CLIL/EMILE: The European dimension: actions, trends and foresight potential. Jyväskylä : UniCOM.

14. Marsh, D. (n.d.). Using Languages to Learn and Learning to Use Languages. Retrieved January 21, 2018, from 〈http://archive.ecml.at/mtp2/clilmatrix/pdf/1uk.pdf).

15. Mehisto, P. 2012. Criteria for Producing CLIL Learning Materials. Encuentro 21. 15-33.

16. Mehisto, P., Marsh, D., \& Frigols, M. J. 2008. Uncovering CLIL: content and language integrated learning in bilingual and multilingual education. Oxford : Macmillan Education.

17. Modi, K. 2012. Story Telling in Mathematics. Voice of Research. 1(2), 31-33.

18. Navés, T., C. Muñoz, a M. Pavesi, 2002. Second Language Acquisition for Content and Language Integrated Learning. In G. Langé \& P. Bertaux (Eds.), The CLIL Professional Development Course (pp. 53-102). Milano : Ministero della' Istruzione della' Università e della Ricerca. Direzione Regionale per la Lombardia. Retrieved December 21, 2014, from /http:// lada.fil.ub.es/Angles/CLIL/Docs/SLAforCLILNavesMunozPavesi2002.pdf).

19. Novotná, J. 2011. Učitel metody CLIL. Integrovaná výuka cizího jazyka a odborného předmětu - CLIL: sborník z konference. Praha : VÚP, pp. 14-16.

20. Nunes, T., Schliemann, A. D., \& Carraher, D. W. 1993. Street mathematics and school mathematics. Cambridge : Cambridge University Press.

21. Ouazizi, K. 2016. The Effects of CLIL Education on the Subject Matter (Mathematics) and the Target Language (English). Latin American Journal of Content \& Language Integrated Learning. 9(1), 110-137. doi:10.5294/laclil.2016.9.1.5.

22. Papaja, K. 2014. Focus on CLIL: a qualitative evaluation of content and language integrated learning (CLIL) in Polish secondary education. Newcastle upon Tyne : Cambridge Scholars Publishing.

23. Pavesi, M., Bertocchi, D., Hofmannová, M., Kazianka, M. 2001. CLIL Guidelines for Teachers. Milan : TIE CLIL.

24. Pica, T. 2002. Subject-Matter Content: How Does It Assist the Interactional and Linguistic Needs of Classroom Language Learners? The Modern Language Journal. 86(1), 1-19. doi:10.1111/1540-4781.00133.

25. Pokrivčáková, S., 2010. Obsahovo integrované učenie sa cudzieho jazyka (CLIL) na 1. stupni ZŠ, 2010. In Straková, Z., Cimermanová, I. (Eds.): Učitel' cudzieho jazyka v kontexte primárneho vzdelávania. Prešov : Prešovská univerzita, 99-121.

26. Sepešiová, M. 2014. Profesijné kompetencie učitel'a CLIL v primárnej edukácii. Prešov : Prešovská univerzita v Prešove.

27. Sepešiová, M., Straková, Z. 2013. Obsahovo a jazykovo integrované vyučovanie (CLIL) a bilingvizmus v primárnej edukácii. In Na ceste za dvojjazyčnost'ou: od informálneho $k$ formálnemu vzdelávaniu. Roma : DITI, 2013. ISBN 978-88-88677-10-1. pp. 122-159.

28. Skeet, J. 2011. Reflections on CLIL. Retrieved January 21, 2018, from /http://clilreflections. blogspot.sk/2011/12/8-cs-of-clil.html>.

29. Sousa, D. A. 2015. How the brain learns mathematics. Corwin : Thousand Oaks. 
30. Tejkalová, L. 2010. Clil as a Challenge for Mathematics Teacher Trainee S. Identifying Teacher Competences Mathematics and Language Integrated Learning. Retrieved January 26, 2018, from 〈http://math.unipa.it/ grim/YESS-5/PaperTejkalova.pdf〉.

31. Tennant, R. 2002. Interdisciplinary Teaching Strategies in the World of Humanistic Mathematics. VISMATH, Visual Mathematics: Art and Science Electronic Journal. 4(4). Retrieved January 26, 2018, from 〈http://www.mi.sanu.ac.rs/vismath/pap.htm\#n42〉.

32. Trníková, J. 2015. Primary CLIL. In Pokrivčáková, S. et al., CLIL and Foreign Language Education. Nitra : SlovakEdu.

33. Toor, A., Mgombelo, J. (2015). Teaching mathematics through storytelling: Engaging the 'being' of a student in mathematics. In Konrad Krainer; Nada Vondrova: CERME 9 - Proceedings of the Ninth Congress of the European Society for Research in Mathematics Education. Prague, Czech Republic : Charles University in Prague, Faculty of Education, pp. 3276-3282.

34. Vanková, Š. 2012. CLIL jako jedna z inovativních metod v současném vzdělávání. Teoretické reflexe hudební výchovy. (8) 1,31-38.

35. Vašíček, Z. 2008. Hra na klavír s komunikací v cizím jazyce (anglicky nebo německy) čili CLIL: Základy - I. díl. Brno : JAMU.

36. Ward-Penny, R. 2011. Cross-curricular teaching and learning in the secondary school - mathematics. London : Routledge.

37. Wrangles P. 2017. Hodder Cambridge Primary Mats: Workbook. London : Hodder Education.

\section{Contact}

doc. PaedDr. Ivana Cimermanová, PhD.

IAA FF Prešovská univerzita

Ul. 17. novembra 1, Prešov

cimermanova@unipo.sk 